\title{
The inventions in nanotechnologies as practical solutions. Part III
}

\author{
Authors: \\ Leonid A. Ivanov, \\ Vice President, the International Academy of Engineering, Moscow, Russian Federation, \\ L.a.ivanov@mail.ru;
}

\section{Petr S. Prokopiev,}

Student, Financial University Under the Government of the Russian Federation, International Economic Relations Faculty, e-mail: prokopiev2012@gmail.com

\begin{abstract}
A brief review of patents is given. The research performed by scientists, engineers and specialists in the area of nanotechnologies and nanomaterials resulted in increased efficiency of construction, housing sector and adjacent fields of economy. For example, the invention «Construction structural element» refers to the field of construction. The building element is made of a cured mixture containing the following components, wt. \%: dispersed foamglass $-60-85 ; 25-30 \%$ alumina solution in phosphoric acid - 13-34; basalt microfiber - 2-6; fulleroid type carbon toroid-like nanoparticles (fractions from 15 to $150 \mathrm{~nm}$ ) - 0.009-0005. The dispersed foamglass is made in the form of foamed glass beads, on the surface of which a layer of polyparaxilylene 2-5 microns thick is applied. The mixture is cured at a temperature of $160-180^{\circ} \mathrm{C}$. The technical result is increased strength, toughness, crack resistance and durability at low density, that is important when building objects, for example, to create internal walls and cellular partitions in rooms.

The specialists can also be interested in the following inventions in the area of nanotechnologies: composite reinforcement, a method of manufacturing composite powder material from alumina carbon nanotubes; the method of plasma deposition of nanostructured heat-shielding coating; the method of degassing tungsten nanopowder; method to produce mixtures of highly dispersed heterophase powders based on boron carbide, etc.
\end{abstract}

Keywords: nanotechnologies in construction, carbon nanotubes, nanocomposite material, nanoparticles, nanostructured coating, nano- and microparticles, nanocrystalline coating.

For citation: Ivanov LA., Prokopiev P.S. The inventions in nanotechnologies as practical solutions. Part III. Nanotehnologii v stroitel'stve = Nanotechnologies in Construction. 2019, Vol. 11, no.3, pp. 292-303. DOI: 10.15828/2075-8545-2019-11-3-292-303.

Machine-readable information on CC-licenses (HTML-code) in metadata of the paper

$<$ rel="license" href="http://creativecommons.org/licenses/by/4.0/" ><img alt="Creative Commons License" style="border-width:0" src="https://i.creativecommons.org/l/by/4.0/88x31.png" / ></a $><$ br $/><$ span xmlns:dct="http://purl.org/dc/terms/" href="http://purl.org/dc/dcmitype/Text" property="dct:title" rel="dct:type" $>$ The inventions in nanotechnologies as practical solutions. Part III</span $>$ by $<$ a xmlns:cc="http://creativecommons.org/ns\#" href="Nanotehnologii v stroitel'stve $=$ Nanotechnologies in Construction. 2019, Vol. 11, no.3, pp. 292-303. DOI: 10.15828/2075-8545-2019-11-3-292-303" property="cc:attributionName" rel="cc:attributionURL">Ivanov LA., Prokopiev P.S. $<$ /a $>$ is licensed under a $<$ a rel="license" href="http://creativecommons.org/licenses/by/4.0/" $>$ Creative Commons Attribution 4.0 International License $</ \mathrm{a}>$.<br/>Based on a work at $<$ a xmlns:dct="http://purl.org/dc/terms/" href="http://nanobuild.ru/en_EN/nanobuild-3-2019/" rel="dct:source" $>$ http://nanobuild.ru/en_EN/nanobuild-3-2019/</a $>.<\mathrm{br} />$ Permissions beyond the scope of this license may be available at $<$ a xmlns:cc="http://creativecommons.org/ns\#" href="L.a.ivanov@mail.ru" rel="cc:morePermissions">L.a.ivanov@mail.ru</a $>$.

The paper has been received by editors: 10.04.2019.

The paper has been received by editors after peer-review: 07.05.2019.

The paper has been accepted for publication: 17.05.2019. 


\title{
Изобретения в области нанотехнологий, направленные на решение практических задач. Часть III
}

\author{
Авторы: \\ Иванов Леонид Алексеевич, \\ вице-президент, Международная инженерная академия, \\ г. Москва, Россия, L.a.ivanov@mail.ru \\ Прокопьев Пётр Сергеевич, \\ студент факультета международных экономических отношений Финансового университета \\ при Правительстве Российской Федерации, prokopiev2012@gmail.com
}

Резюме: В реферативной форме проводится обзор изобретений. Результаты творческой деятельности ученых, инженеров и специалистов, В Т.ч. и изобретения в области нанотехнологий и наноматериалов, позволяют в строительстве, жилищнокоммунальном хозяйстве, смежных отраслях экономики добиться значительного эффекта. Например, изобретение «Строительный конструкционный элемент» относится к области строительства. Строительный элемент выполнен из отвержденной смеси, содержащей следующие компоненты, мас. \%: дисперсное пеностекло - 60-85; 25-30\%-ный раствор оксида алюминия в ортофосфорной кислоте - 13-34; базальтовая микрофибра - 2-6; углеродные тороподобные наночастицы фуллероидного типа (фракции от 15 до 150 нм) - 0,009-0005. Дисперсное пеностекло выполнено в виде вспененных стеклошариков, на поверхность которых нанесен слой полипараксилилена толщиной 2-5 мкм. Отверждение смеси производят при температуре $160-180^{\circ} \mathrm{C}$. Технический результат заключается в повышении прочности, ударной вязкости, трещиностойкости и долговечности при малой плотности издедий, что важно при строительстве объектов, например, для создания внутренних стен и сотовых перегородок в помещениях.

Также представляют интерес для специалистов следующие изобретения в области нанотехнологий: арматура композитная; способ изготовления композитного порошкового материала из алюмооксидных углеродных нанотрубок; способ плазменного нанесения наноструктурированного теплозащитного покрытия; способ дегазации нанопорошка вольфрама; способ получения смесей высокодисперсных гетерофазных порошков на основе карбида бора и др.

Ключевые слова: нанотехнологии в строительстве, углеродные нанотрубки, нанокомпозитный материал, наночастицы, наноструктурированное покрытие, нано- и микрочастицы, нанокристаллическое покрытие.

Для цитирования: Иванов Л.А., Прокопьев П.С. Изобретения в области нанотехнологий, направленные на решение практических задач. Часть III // Нанотехнологии в строительстве. - 2019. - Том 11, № 3. - С. 292-303. - DOI: 10.15828/20758545-2019-11-3-292-303.

Machine-readable information on CC-licenses (HTML-code) in metadata of the paper

$<$ rel="license" href="http://creativecommons.org/licenses/by/4.0/" $><$ img alt="Creative Commons License" style="border-width:0" src="https://i.creativecommons.org/l/by/4.0/88x31.png" / $></ \mathrm{a}><$ br $/><$ span xmlns:dct="http://purl.org/dc/terms/" href="http://purl.org/dc/dcmitype/Text" property="dct:title" rel="dct:type" $>$ The inventions in nanotechnologies as practical solutions. Part III $</$ span $>$ by $<$ a xmlns:cc="http://creativecommons.org/ns\#" href="Nanotehnologii v stroitel'stve = Nanotechnologies in Construction. 2019, Vol. 11, no.3, pp. 292-303. DOI: 10.15828/2075-8545-2019-11-3-292-303" property="cc:attributionName" rel="cc:attributionURL">Ivanov LA., Prokopiev P.S. $</$ a $>$ is licensed under a $<$ a rel="license" href="http://creativecommons.org/licenses/by/4.0/" $>$ Creative Commons Attribution 4.0 International License $</ a>.<$ br $/>$ Based on a work at $<$ a xmlns:dct="http://purl.org/dc/terms/" href="http://nanobuild.ru/en_EN/nanobuild-3-2019/" rel="dct:source" $>$ http://nanobuild.ru/en_EN/nanobuild-3-2019/</a $>$. $<$ br $/>$ Permissions beyond the scope of this license may be available at $<$ a xmlns:cc="http://creativecommons.org/ns\#" href="L.a.ivanov@mail.ru" rel="cc:morePermissions" $>$ L.a.ivanov@mail.ru</a $>$.

Статья поступила в редакцию: 10.04.2019.

Статья поступила в редакцию после рецензирования: 07.05.2019.

Статья принята к публикации: 17.05.2019. 


\section{INTRODUCTION}

The practical application of the results achieved by scientists, engineers and specialists can become efficient tool to increase number of import-substituting goods and to rise labor productivity. An invention is known to be a new, with distinctive characteristics technical solution with proved efficiency (new technologies, structures or new substances). The paper reviews the essence, technical result and practical value of some inventions concerning nanotechnologies.

\section{MAIN PART}

\section{Construction structural element (RU 2683836 C1)}

The problem solved through the invention is the creation of a building structural element of arbitrary shape with enhanced performance characteristics, in particular, with increased strength, toughness, crack resistance and durability with relatively low specific density, which is important, for example, to create internal walls and cellular partitions [1].

The problem is solved, and the required technical result is achieved by the fact that the construction structural element is made of cured mixture with dispersed foam glass. According to the invention, the mixture contains additional components that are mixed with dispersed foam glass before curing as part of a concentrated solution of aluminum oxide in phosphoric acid, basalt microfiber and carbon toropodobny nanoparticles with the following mass ratio. \%:

- dispersed foamglass $-60-85$;

- 25-30\% alumina solution in phosphoric acid - 13-34;

- basalt microfiber (fraction 80-600 microns) - 2-6;

- carbon toropodobnye nanoparticles of the fulleroid type (fraction from 15 to $150 \mathrm{~nm}$ ) $-0.009-0,0005$.

The mixture is cured at a temperature of $140-180^{\circ} \mathrm{C}$, and before mixing additional components with dispersed foam glass made in the form of foamed glass beads, a layer of $2-5$ microns of a chemically resistant polymer (polyparaxilylene) which thick is $2-5$ microns is applied to them from the gas phase.

\section{Composite reinforcement (RU 2684271 C1)}

The invention provides an effective consumption of nanocomposite in dependence on the diameter of the produced reinforcement, thus providing the possibility of obtaining reinforcement with a modulus of elasticity of the order of Ep $=200000 \mathrm{MPa}$ with reduced consumption of nanomaterial [2].

The composite reinforcement contains a carrier core of basalt or glass roving and high modulus fibers impreg- nated with a binder that consists of epoxy resin, hardener, plasticizer with the addition of carbon nanocomposite containing multilayer carbon nanotubes in an amount of at least $45-50 \%$ of its mass formed by pyrolysis sphagnum brown with mechanical activation of pyrolysis products for at least 8 hours. The content of carbon nanocomposite in $\%$ of the volume of epoxy resin depends on the diameter of the supporting rod. When the diameter of the supporting rod is $6 \mathrm{~mm}$, the content of the carbon nanocomposite is $0.3-0.4 \%$; when the diameter of the supporting rod is $8 \mathrm{~mm}$, the content of the carbon nanocomposite is $0.4-0.5 \%$; when the diameter of the supporting rod is $10 \mathrm{~mm}$, the content of carbon nanocomposite is $0,5-0.6 \%$, when the diameter of the supporting rod is $12 \mathrm{~mm}$, the content of the carbon nanocomposite is $0.6-0.7 \%$, and when the diameter of the supporting rod is $14 \mathrm{~mm}$, the content of the carbon nanocomposite is $0.7-0.8 \%$, when the diameter of the supporting rod is $16 \mathrm{~mm}$ content of carbon nanocomposite is $0.8-0.9 \%$; moreover, when the diameter of the supporting rod is equal to and greater than $20 \mathrm{~mm}$, the content of the carbon nanocomposite is $1.00 \%$.

A method of manufacturing composite powder material from alumina carbon nanotubes (RU 2683323 C1)

The purpose of the invention is to provide a method of manufacturing composite powdered material in the form of alumina carbon tubes. In the course of the method a carbon nanotube is placed on the surface of a ceramic alumina powder. That results in generating nickel, iron, cobalt and other metallic nanoparticles (catalysts) on the surface of an alumina ceramic powder by splitting the organometallic precursor. Due to this carbon in the organometallic precursor and carbon carbon gases, for example, methane, is cleaved and catalyzed to generate a carbon nanotube, and the length, diameter, and microstructure of the carbon nanotube are controlled by changing several factors, including the feed volume, the speed of rotation, and the reaction temperature, which shortens the production period and reduces costs, because the subsequent stage of the carbon nanotube production is lowered, and also improves the dispersion uniformity and efficiency of the carbon nanotube [3].

Moreover, since the carbon nanotube has the characteristics of a one-dimensional nanostructure, the ratio of length to diameter is large. At the same time, due to the large van der Waals force and a large specific area between carbon nanotubes, such a tube can easily exist as a complex filler. The method of obtaining and distributing carbon nanotubes in alumina powder can be a key factor in achieving high performance of a carbon nanotube. 


\section{The method of plasma application of nanostructured heat-shielding coating (RU 2683177 C)}

The invention relates to a method for the plasma application of nanostructured heat shield [4]. At first a conical nozzle is installed on the section of the supersonic plasma torch nozzle, the inner surface of which forms a fracture with the inner surface of the nozzle, which allows the plasma pressure with the sprayed substance in the wall part of the nozzle to be set equal to the pressure in the vacuum chamber after the fracture. The plasma torch and the substrate is installed in the chamber with reduced pressure. A dynamic vacuum is maintained in the chamber, the plasma-forming gas and powder of the sprayed substance are fed into the plasma torch and the substance is sprayed with a supersonic plasma flow with the formation of molten particles of micron level and vapor phase of the sprayed substance. Then, nanoparticles formed in the wall part of the nozzle and particles of micron level of the sprayed substance are deposited onto the substrate. The substrate is moved in such a way that the layers of nanoparticles and particles of micron level of the sprayed substance overlap each other.

The technical result achieved by the claimed method consists in simultaneously increasing the adhesive and cohesive strength of the coating, increasing its heat resistance when using the entire sprayed material falling on the substrate in the form of particles of micron level and in the form of nanoparticles.

The method of forming multilayer coating on particles and device for its implementation (RU 2683115 C1)

The group of inventions relates to the field of chemistry, in particular to equipment for chemical or physical laboratories and the method of their use, and can be used to form multi-layer composite coatings on submicro- or microparticles by the layer-by-layer adsorption method [15]. The method of forming a multilayer coating on particles consists of following stages: alternate application of layers of nanomaterial on submicro or microparticles, washing the particles after each layer is applied in the working module, which has two channels separated by a filtration membrane, by supplying a stream of particles with a deposited layer of nanomaterial to one of the channels and flushing fluid - to another channel. The first application is carried out by feeding into one of the channels of the nanomaterial, and in the other - the flow of submicro- or microparticles. Each subsequent application after washing is carried out by feeding submicro- or microparticles with a deposited layer of nanomaterial into one of the channels, and a flow of nanomaterial into the other channel. The application and washing is carried out at the same pressure and speed. The streams of particles and nanomaterial are fed parallel to the surface of the fil- tration membrane, which is permeable for the molecules of the nanomaterial and impermeable for submicro or microparticles.

The technical result of these inventions is increased efficiency of the process of forming multilayer coating on particles by the method of layer-by-layer adsorption due to the implementation of the flow-through deposition process while expanding the spectrum of nanomaterials used and preserving automation.

The method of obtaining mixtures of highly dispersed heterophase powders based on boron carbide (RU 2683107 C1)

The invention relates to ceramic technology and powder metallurgy and is intended to produce highly dispersed heterophase powder compositions that can be used for the production of ceramic armor elements and materials operating under conditions of abrasive wear, products used in mechanical engineering, energy and chemical technologies in aerospace engineering. The required powders are obtained by reducing a mixture of oxides of boron, silicon and/or d-metal with highly dispersed carbon (soot) in a vacuum or in a protective gaseous medium at temperatures of $1500-1800^{\circ} \mathrm{C}$. Powders of boric acid, boric anhydride, silicon oxide, and transition d-metal oxide of the secondary group IV-VI of the Periodic Table of the Elements [6] can be used as basic substances.

To ensure uniform distribution of components and high dispersion of mixtures, the initial oxygen-containing substances are pre-homogenized by melting them together in air with the subsequent formation of precursors in the glass-crystalline state containing oxide components necessary for the synthesis, which are uniformly distributed at the atomic-ionic level directly in the glass-ceramic precursor. This homogenization prevents the formation of agglomerates of particles of one of the components by shielding the particles of the synthesized components from each other, which increases the diffusion path of the atoms and complicates the process of secondary recrystallization, which results in highly dispersed synthesis products.

The method of obtaining composite lithium orthovanadate / carbon (RU 2683094 C1)

The invention relates to a method for producing composites in a finely dispersed state, in particular, the lithium orthovanadate / carbon Li3VO4 / C composite, which can be used as an effective anode material of chemical current sources [7]. The research problem is solved in the proposed method of obtaining a composite lithium orthovanadate / carbon composition $\mathrm{Li} 3 \mathrm{VO} 4 / \mathrm{C}$, including hydrothermal treatment of the re- 
action mixture containing vanadium compound, lithium compound and glucose, followed by filtration, washing, drying and annealing in an inert atmosphere, in which ammonium metavanadate is used in vanadium, lithium hydroxide monohydrate is used as a lithium compound, and the molar ratio of the components of ammonium metavanadate: monohydrate is lithium hydroxide: glucose is $1: 3: 0.5 \div 2$, and the hydrothermal treatment is carried out with microwave radiation of $17-19 \mathrm{~W}$ with constant stirring at a speed of $100-300 \mathrm{rpm}$ at a temperature of $160-220^{\circ} \mathrm{C}$ and a pressure of $10-15$ bar for 5-20 min, and the annealing is carried out at a temperature of $500-650^{\circ} \mathrm{C}$ for $1-2$ hours.

Conditions of microwave processing with continuous stirring promotes the homogenization of the final product. This approach to the implementation of the process of obtaining a composite $\mathrm{Li} 3 \mathrm{VO} 4$ / C ensures the reliability of the uniform distribution of the carbon component of the composite. Homogeneous dispersion of carbon in the composite prevents aggregation of the particles of the final product, which ultimately increases the stability of various devices made on the basis of the lithium orthovanadate / carbon composite as a material.

\section{Low-temperature plastic lubricant (RU 2682881 C1)}

The invention relates to the creation of low-temperature lubricant, which can be used in mechanisms for various purposes, operating at temperatures from minus $60^{\circ} \mathrm{C}$. Essence: low-temperature lubricant contains, mass \%: thickener 11.0-15.0, antioxidant amine and / or phenolic type $0.3-0.5$, nanostructured functional additive - nanosized particles of halloysite or montmorillonite $0.5-5.0$, an additive with anti-wear and / or anti-scuff properties of $0.0-3.0$, a corrosion inhibitor $0.0-2.0$, base oil - the rest, up to 100 . Moreover, when forming a lubricant, the specified nanostructured functional additive is used as a pre-mechanically dispersed in base oil, and after mixing with the other components is thermomechanically dispersed in a mixture of these components [8].

If necessary, calculated amounts of additives (antiwear and / or extreme pressure, corrosion inhibitor) are added to the cooled lubricant, and then they are subjected to mechanical processing (in particular, homogenization, filtration, deaeration). Thus, the nanostructured functional additive is thermomechanically dispersed in the mixture of these components. It is assumed that the introduction of nanoscale particles into the composition prior to the stage of thermomechanical dispersion has a significant influence on the formation of the dispersed phase due to their incorporation into the structural framework of the thickener used. This process of modifying the structural frame has a positive effect on the tribological characteristics of the lubricant.

\section{Effective spin-photon interaction when using a wave- guide symmetric in the glide plane (RU $2682559 \mathrm{C}$ )}

The group of inventions relates to optical devices containing a waveguide for reading quantum emitters. The optical device contains a planar waveguide and a quantum emitter. The planar waveguide comprises a longitudinally extending guide region with a first side and a second side. The first nanostructure is located on the first side of the guide region. The second nanostructure is located on the second side of the guide region. A planar waveguide includes a longitudinal region, where the first nanostructure and the second nanostructure are located essentially symmetrically in the slip plane relative to the guide region of the planar waveguide [9].

The quantum emitter is connected with the first longitudinal region of the planar waveguide. The quantum emitter is embedded in the guide region of the planar waveguide so that the emitter is a single photon emitter and emits photons in a circularly polarized mode. The longitudinal region of the planar waveguide supports the modes when the electric fields are circularly polarized in the plane of the planar waveguide in the position of the quantum emitter. Thus, photons from a single photon emitter are effectively introduced into a planar waveguide. The technical result consists in obtaining a waveguide, which ensures efficient reading of quantum emitters on a crystal, having dipole moments of transitions with circular polarization.

\section{Method of degassing tungsten nanopowder (RU 2681962 C1)}

The invention relates to the field of powder metallurgy, in particular to the purification of tungsten nanopowder. It can be used to remove sorbed gases and water from the surface and from the volume of the powder during its preparation for further use in the process. The degassing is carried out by irradiating the sample with microwave radiation in an atmosphere of air with pulses of duration from 5 to $3000 \mathrm{~ns}$, a wavelength of $10 \mathrm{~cm}$, a pulse repetition rate of not more than $50 \mathrm{~Hz}$ for at least 1 minute. The degassing of chemical compounds absorbed by the powder is provided [10].

The proposed method allows solving the technical problem of degassing molecules of chemical compounds sorbed by tungsten nanopowder $\left(\mathrm{H}_{2} \mathrm{O}, \mathrm{CO}_{2}, \mathrm{O}_{2}\right.$, etc. $)$, as well as in the prototype, involves irradiating the sample with electromagnetic radiation to ensure desorption of sorbed chemical compounds.

The method provides degassing of tungsten nanopowder by desorption of $4.2 \mathrm{wt} . \%$ of chemical compounds contained in the untreated tungsten nanopowder due to rapid short-term heating of tungsten nanoparticles by pulsed microwave radiation. 


\section{These are inventions in nanotechnological area that can be interesting for specialists:}

- A method to produce nanoporous polymers [11].

- Technology for recycling valuable components of municipal solid waste [12].

- Wastewater treatment from heavy metal ions using nanoactivated complexes of natural zeolite and diatomite [13].

- Detonation nanodiamond surface functionalization method [14].

- Heat-shielding nanocomposite coating and method of its formation [15].

- A method to introduce single-wall and/or two-wall and/or multi-wall carbon nanotubes in composition of adhesive additives for asphalt coating and application of single-wall and/or two-wall and/or multi-wall carbon nanotubes in composition of adhesive additives [16].

- Natural gas storage method using adsorption in industrial gas cylinders [17].

- Method for the production of rubber ionomers and polymer nanocomposites [18].
- Device and method for production of powder materials based on nano- and microparticles through electric explosion of wire [19].

- Energy-saving technologies in the power supply of smart buildings with artificial intelligence [20].

- New regional models of economic development [21].

- Integration processes in energy markets [22].

\section{CONCLUSION}

It is known that it is popularization and introduction of inventions that is an important factor for the success of many successful companies. For example, General Electric, which entered world history as one of the most innovative companies of the $20^{\text {th }}$ century, is a company that was originally listed in the Dow Jones index in 1896 and is still there. Therefore, we hope that the information published in this section will be useful for specialists. The high demand for the articles from the «Invention Review» column is proved by the number of views of materials, for example, in the full-text database of open access scientific journals Open Academic Journals Index OAJI (USA), link - http:// oaji.net/ journal-detail.html? number $=6931$.

\section{ВВЕДЕНИЕ}

В современных условиях использование изобретений ученых, инженеров и специалистов может способствовать эффективному решению задач импортозамещения и повышения производительности труда. Как известно, изобретение - это новое, обладающее существенными отличиями решение технической задачи, обеспечивающее положительный эффект (новые технологии, конструкции, новые вещества). В статье рассмотрены сущность, технический результат, практическая значимость некоторых изобретений, относящихся к области нанотехнологий.

\section{ОСНОВНАЯ ЧАСТЬ}

\section{Строительный конструкционный элемент (RU 2683836 C1)}

Задачей, решаемой в изобретении, является создание строительного конструкционного элемента произвольной формы с повышенными эксплуатационными характеристиками, в частности, с повышенной прочностью, ударной вязкостью, трещиностойкостью и долговечностью при относительно малой удельной плотности, что важно, например, для создания внутренних стен и сотовых перегородок в помещениях [1].

Поставленная задача решается, а требуемый технический результат достигается тем, что строительный конструкционный элемент выполнен из отвержденной смеси, содержащей дисперсное пеностекло. Согласно изобретению, смесь содержит дополнительные компоненты, которые смешивают с дисперсным пеностеклом перед отверждением в составе концентрированного раствора оксида алюминия в ортофосфорной кислоте, базальтовой микрофибре и углеродных тороподобных наночастицах при следующем соотношении масс. \%:

- дисперсное пеностекло - 60-85;

- 25-30\%-й раствор оксида алюминия в ортофосфорной кислоте - 13-34;

- базальтовая микрофибра (фракция 80-600 мкм) 2-6;

- углеродные тороподобные наночастицы фуллероидного типа (фракции от 15 до 150 нм) - 0,0090,0005 .

Отверждение смеси производят при температуре $140-180^{\circ} \mathrm{C}$, а перед смешиванием дополнительных компонентов с дисперсным пеностеклом, выполненным в виде вспененных стеклошариков, из газовой фазы на них наносят слой толщиной 2-5 мкм 
химически стойкого полимера (полипараксилилена) толщиной 2-5 мкм.

\section{Арматура композитная (RU 2684271 C1)}

Изобретение обеспечивает эффективный расход нанокомпозита в зависимости от диаметра производимой арматуры, при этом обеспечивается возможность получения арматуры с модулем упругости порядка $\mathrm{E}_{\mathrm{p}}=200000$ МПа при пониженном расходе наноматериала [2].

Арматура композитная содержит несущий стержень из базальтового или стеклянного ровинга и высокомодульные волокна, пропитанные связующим, включающим эпоксидно-диановую смолу, отвердитель, пластификатор с добавкой углеродного нанокомпозита, содержащего многослойные углеродные нанотрубки в количестве не менее 45-50\% от его массы, сформированного пиролизом сфагнума бурого с механоактивацией продуктов пиролиза в течение не менее 8 часов. Содержание углеродного нанокомпозита в \% от объема эпоксидно-диановой смолы зависит от диаметра несущего стержня. При диаметре несущего стержня 6 мм содержание углеродного нанокомпозита составляет 0,3-0,4\%, при диаметре несущего стержня 8 мм содержание углеродного нанокомпозита составляет 0,4-0,5\%, при диаметре несущего стержня 10 мм содержание углеродного нанокомпозита составляет 0,5-0,6\%, при диаметре несущего стержня 12 мм содержание углеродного нанокомпозита составляет 0,6-0,7\%, при диаметре несущего стержня 14 мм содержание углеродного нанокомпозита составляет 0,7-0,8\%, при диаметре несущего стержня 16 мм содержание углеродного нанокомпозита составляет 0,8-0,9\%, причем при диаметре несущего стержня, равном и превышающем 20 мм, содержание углеродного нанокомпозита составляет $1,00 \%$.

Способ изготовления композитного порошкового материала из алюмооксидных углеродных нанотрубок (RU 2683323 C1)

Цель изобретения - предоставление метода получения композитного порошкообразного материала в виде алюмооксидных углеродных трубок, представляющего собой метод помещения углеродной нанотрубки на поверхность керамического порошка оксида алюминия, вследствие чего на поверхности керамического порошка из оксида алюминия генерируются никель, железо, кобальт и другие металлические наночастицы (катализаторы) посредством расщепления органометаллического прекурсора, вследствие чего углерод в органометаллическом прекурсоре и углеродсодержащих газах, например, метане, расщепляется и катализируется для генерирования углеродной нанотрубки, и длина, диаметр и микроструктура углеродной нанотрубки контролируются посредством изменения нескольких факторов, включая объем подачи сырья, скорость вращения и температуру реакции, что сокращает период получения и снижает затраты, так как последующий этап получения углеродной нанотрубки опускается, а также улучшает однородность дисперсии и эффективность углеродной нанотрубки [3].

При этом ввиду того, что углеродная нанотрубка имеет характеристики одномерной наноструктуры, отношение длины к диаметру велико. В то же время, ввиду большой силы Ван-дер-Ваальса и обширной удельной площади между углеродными нанотрубками, такая трубка легко может существовать в виде сложного наполнителя. Способ получения и распределения углеродных нанотрубок в алюмооксидном порошке может стать ключевым фактором достижения высокой производительности углеродной нанотрубки.

Способ плазменного нанесения наноструктурированного теплозащитного покрытия (RU 2683177 C)

Изобретение относится к способу плазменного нанесения наноструктурированного теплозащитного покрытия [4]. Предварительно на срезе сверхзвукового сопла плазмотрона устанавливают конический насадок, внутренняя поверхность которого образует с внутренней поверхностью сопла излом, что позволяет после излома установить давление плазмы с напыляемым веществом в пристеночной части насадка, равным давлению в вакуумной камере. Плазмотрон и подложку устанавливают в камеру с пониженным давлением. Осуществляют поддержание динамического вакуума в камере, подачу плазмообразующего газа и порошка напыляемого вещества в плазмотрон и распыление вещества сверхзвуковым потоком плазмы с образованием расплавленных частиц микронного уровня и паровой фазы напыляемого вещества. Затем обеспечивают выпадение на подложку наночастиц, образующихся в пристеночной части насадка, и частиц микронного уровня напыляемого вещества. Подложку перемещают таким образом, чтобы слои из наночастиц и частиц микронного уровня напыляемого вещества перекрывали друг друга.

Технический результат, достигаемый заявленным способом, состоит в одновременном повышении адгезионной и когезионной прочности покрытия, увеличении его теплостойкости, при использовании всего напыляемого материала, выпадающего на подложку в виде частиц микронного уровня и в виде наночастиц. 
Способ формирования многослойного покрытия на частицах и устройство для его реализации (RU 2683115 C1)

Группа изобретений относится к области химии, в частности к оборудованию для химических или физических лабораторий и способу их применения, и может быть использована для формирования многослойных композитных покрытий на субмикро- или микрочастицах методом послойной адсорбции [15]. Способ формирования многослойного покрытия на частицах заключается в поочередном нанесении слоев наноматериала на субмикро- или микрочастицы, промывке частиц после каждого нанесения слоя в рабочем модуле, имеющем два канала, разделенных фильтрационной мембраной, путем подачи в один из каналов потока частиц с нанесенным слоем наноматериала, а в другой - промывочной жидкости. Первое нанесение осуществляют путем подачи в один из каналов наноматериала, а в другой - потока субмикро- или микрочастиц. Каждое последующее нанесение после промывки осуществляют путем подачи в один из каналов потока субмикроили микрочастиц с нанесенным слоем наноматериала, а в другой - потока наноматериала. Нанесение и промывку осуществляют при одинаковом давлении и скорости. Потоки частиц и наноматериала подают параллельно поверхности фильтрационной мембраны, выполненной проницаемой для молекул наноматериала и непроницаемой для субмикро- или микрочастиц.

Техническим результатом группы изобретений является повышение эффективности процесса формирования многослойного покрытия на частицах методом послойной адсорбции за счет реализации проточного процесса нанесения при расширении спектра используемых наноматериалов и сохранении автоматизации.

Способ получения смесей высокодисперсных гетерофазных порошков на основе карбида бора (RU 2683107 C1)

Изобретение относится к керамической технологии и порошковой металлургии и предназначено для получения высокодисперсных гетерофазных порошковых композиций, которые могут быть использованы для производства керамических бронеэлементов, материалов, работающих в условиях абразивного износа изделий, применяемых в машиностроении, в энергетических и химических технологиях, в аэрокосмической технике. Требуемые порошки получают путем восстановления смеси оксидов бора, кремния и/или d-металла высокодисперсным углеродом (сажей) в вакууме или в защитной газовой среде при температурах $1500-1800^{\circ} \mathrm{C}$. В качестве исходных веществ могут быть использованы порошки борной кислоты, борного ангидрида, оксида кремния, оксида переходного d-металла побочной подгруппы IV-VI групп Периодической системы элементов [6].

Для обеспечения однородности распределения компонентов и высокой дисперсности смесей исходные кислородсодержащие вещества предварительно гомогенизируют путем их совместного плавления в воздушной среде с последующим образованием прекурсоров в стеклокристаллическом состоянии, содержащих необходимые для синтеза оксидные компоненты, равномерно распределенные на атомно-ионном уровне непосредственно в структуре стеклокристаллического прекурсора. Указанная гомогенизация препятствует образованию агломератов частиц одного из компонентов за счет экранирования частиц синтезируемых компонентов друг от друга, которое увеличивает диффузионный путь одноименных атомов и затрудняет процесс вторичной рекристаллизации, что приводит к получению высокодисперсных продуктов синтеза.

Способ получения композита ортованадат лития/ углерод (RU 2683094 C1)

Изобретение относится к способу получения композитов в мелкодисперсном состоянии, в частности, композита ортованадат лития/углерод Li3VO4/C, который может быть использован в качестве эффективного анодного материала химических источников тока [7]. Поставленная задача исследования решена в предлагаемом способе получения композита ортованадат лития/углерод состава Li3VO4/C, включающем гидротермальную обработку реакционной смеси, содержащей соединение ванадия, соединение лития и глюкозу с последующим фильтрованием, промывкой, сушкой и отжигом в инертной атмосфере, в котором в качестве соединения ванадия используют метаванадат аммония, в качестве соединения лития используют моногидрат гидроксида лития, при этом молярное соотношение компонентов смеси метаванадат аммония : моногидрат гидроксида лития : глюкоза составляет $1: 3: 0.5 \div 2$, а гидротермальную обработку осуществляют микроволновым излучением мощностью 17-19 Вт при постоянном перемешивании со скоростью 100-300 об/мин при температуре $160-220^{\circ} \mathrm{C}$ и давлении 10-15 бар в течение 5-20 мин, а отжиг ведут при температуре $500-650^{\circ} \mathrm{C}$ в течение $1-2$ ч.

Условия микроволновой обработки при непрерывном перемешивании способствует гомогенизации конечного продукта. Такой подход к осуществлению процесса получения композита Li3VO4/C обеспечивает надежность равномерного распределения углеродной составляющей композита. Гомоген- 
ное диспергирование углерода в композите предотвращает агрегацию частиц конечного продукта, что в конечном итоге повышает стабильность работы различных устройств, изготовленных на основе композита ортованадат лития/углерод как материала.

\section{Низкотемпературная пластичная смазка (RU 2682881 C1)}

Изобретение относится к созданию низкотемпературной пластичной смазки, которая может быть использована в механизмах различного назначения, работающих при температуре от минус $60^{\circ} \mathrm{C}$. Сущность: низкотемпературная пластичная смазка содержит, мас.\%: загуститель 11,0-15,0, антиокислитель аминного и/или фенольного типа 0,3-0,5, наноструктурированную функциональную добавку - наноразмерные частицы галлуазита или монтмориллонита 0,5-5,0, присадку с противоизносными и/или противозадирными свойствами 0,0-3,0, ингибитор коррозии $0,0-2,0$, базовое масло - остальное, до 100. Причем при формировании смазки указанную наноструктурированную функциональную добавку используют в виде предварительно механически диспергированной в базовом масле, а после смешения с остальными компонентами - термомеханически диспергированной в смеси указанных компонентов [8].

В охлажденную смазку при необходимости добавляют расчетные количества присадок (противоизносной и/или противозадирной, ингибитора коррозии), после чего подвергают механической обработке (в частности, гомогенизации, фильтрации, деаэрации). Таким образом, наноструктурированная функциональная добавка термомеханически диспергирована в смеси указанных компонентов. Предполагается, что введение наноразмерных частиц в состав до стадии термомеханического диспергирования оказывает значительное влияние на формирование дисперсной фазы за счет их внедрения в структурный каркас используемого загустителя. Указанный процесс модификации структурного каркаса оказывает положительное влияние на трибологические характеристики пластичной смазки.

Эффективное спин-фотонное взаимодействие при использовании симметричного в плоскости скольжения волновода (RU 2682559 C2)

Группа изобретений относится к оптическим устройствам, содержащим волновод для считывания квантовых излучателей. Оптическое устройство содержит планарный волновод и квантовый излучатель. Планарный волновод содержит простирающуюся в продольном направлении направляющую об- ласть с первой стороной и второй стороной. На первой стороне направляющей области расположена первая наноструктура. На второй стороне направляющей области расположена вторая наноструктура. Планарный волновод включает в себя продольную область, где первая наноструктура и вторая наноструктура расположены по существу симметрично в плоскости скольжения относительно направляющей области планарного волновода [9].

Квантовый излучатель связан с первой продольной областью планарного волновода. Квантовый излучатель внедрен в направляющую область планарного волновода так, что излучатель является однофотонным излучателем и излучает фотоны в моде с круговой поляризацией. Продольная область планарного волновода поддерживает моды, когда электрические поля имеют круговую поляризацию в плоскости планарного волновода в положении квантового излучателя. Таким образом, фотоны из однофотонного излучателя эффективно вводятся в планарный волновод. Технический результат заключается в получении волновода, обеспечиваюеег эффективное считывание на кристалле квантовых излучателей, имеющих дипольные моменты переходов с круговой поляризацией.

\section{Способ дегазации нанопорошка вольфрама (RU} 2681962 C1)

Изобретение относится к области порошковой металлургии, в частности к очистке нанопорошка вольфрама. Может быть использовано для удаления сорбированных газов и воды с поверхности и из объема порошка при ее подготовке к дальнейшему использованию в технологическом процессе. Дегазацию осуществляют облучением образца СВЧ-излучением в атмосфере воздуха импульсами длительностью от 5 до 3000 нс, длиной волны 10 см, частотой следования импульсов не более 50 Гц в течение не менее 1 минуты. Обеспечивается дегазация абсорбированных порошком молекул химических соединений [10].

Предлагаемый способ позволяет решить техническую проблему дегазации сорбированных нанопорошком вольфрама молекул химических соединений $\left(\mathrm{H}_{2} \mathrm{O}, \mathrm{CO}_{2}, \mathrm{O}_{2}\right.$ и др.), и так же, как в прототипе, включает облучение образца электромагнитным излучением для обеспечения десорбции сорбированных химических соединений.

Способ обеспечивает дегазацию нанопорошка вольфрама путем десорбции имеющихся в необработанном нанопорошке вольфрама 4,2 мас.\% молекул химических соединений вследствие быстрого кратковременного нагревания наночастиц вольфрама импульсным СВЧ-излучением. 
Также представляют интерес для специалистов следующие изобретения в области нанотехнологий:

- Способ получения нанопористых полимеров [11].

- Технология утилизации ценных компонентов твердых бытовых отходов [12].

- Очистка сточных вод от ионов тяжелых металлов с помощью наноактивированных комплексов природного цеолита и диатомита [13].

- Способ функционализации поверхности детонационных наноалмазов [14].

- Теплозащитное нанокомпозитное покрытие и способ его формирования [15].

- Способ введения одностенных и/или двустенных и/или многостенных углеродных нанотрубок в состав адгезионных добавок для асфальтового покрытия и применение одностенных и/или двустенных и/или многостенных углеродных нанотрубок в составе адгезионных добавок [16].

- Способ хранения природного газа при помощи адсорбции в промышленных газовых баллонах [17].

- Способ производства каучуковых иономеров и полимерных нанокомпозитов [18].

- Устройство и способ для получения порошковых материалов на основе нано- и микрочастиц путем электрического взрыва проволоки [19].
- Энергосберегающие технологии в электроснабжении умных зданий с использованием искусственного интеллекта [20].

- Новые региональные модели экономического развития [21].

- Интеграционные процессы на энергетических рынках [22].

\section{ЗАКЛЮЧЕНИЕ}

Известно, что именно популяризация и внедрение изобретений являются важным фактором успеха многих преуспевающих компаний. Например, General Electric, которая вошла в мировую историю как одна из самых инновационных компаний 20 века, является компанией, которая изначально попала в список индекса Доу-Джонса в 1896 году и до сих пор там находится. Поэтому надеемся, что публикуемая в данной рубрике информация будет востребованной и полезной для специалистов. Подтверждением того, что статьи из рубрики «Обзор изобретений» пользуются особой популярностью, является информация о количествах просмотров материалов, наример, в полнотекстовой базе научных журналов открытого доступа Open Academic Journals Index OAJI (США), ссылка - http://oaji.net/journal-detail. html? number $=6931$.

\section{REFERENCES}

1. Ponomarev A.N., Seredokho V.A., Sofronov A.Yu. Construction structural element. RF Patent 2683836 C1. 2019. Bulletin № 10.

2. Bekker A.T., Umansky A.M. Reinforcement composite. RF Patent 2683836 C1. 2019. Bulletin № 10.

3. Zhang D., Liu Y., Lee G., Su Y., Liang K., Wu Yu., Wu Yu. A method of manufacturing a composite powder material of alumina carbon nanotubes. RF Patent 2683323 C1. 2019. Bulletin №. 10.

4. Gubertov A.M., Polyansky M.N., Savushkina S.V., Chvanov V.K., Levochkin P.S., Sternin L.E. The method of plasma deposition of nanostructured heat-shielding coating. RF Patent 2683177 C1. 2019. Bulletin № 9.

5. German S.V., Gorin D.A., Sukhorukov G.B., Kozlova A.A., Severyukhina A.N. Method of forming multilayer coating on particles and a device for its implementation. RF Patent 2683115 C1. 2019. Bulletin № 9.

6. Kotsar T.V., Danilovich D.P., Zaitsev G.P., Ordanyan S.S. The method of obtaining mixtures of highly dispersed heterophase powders based on boron carbide. RF Patent 2683107 C1. 2019. Bulletin № 9.

7. Zakharova G.S., Dzhu Ts. The method of obtaining a composite lithium orthovanadate / carbon. RF Patent 2683094 C1. 2019. Bulletin № 9.

8. Kolybelsky D.S., Porfiryev Ya.V., Shuvalov S.A., Popov P.S., Zaichenko V.A. et al. Low-temperature lubricant. Patent 2682881 C1. 2019.

9. Mahmudian S., Sellner I.N., Stobbe S., Lodal P. Effective spin-photon interaction when using a waveguide symmetric in the glide plane. Patent 2683836 C2. 2019. Bulletin № 8.

10. Mostovshchikov A.V., Ilin A.P., Chumerin P.Yu., Igumnov V.S. Method of degassing tungsten nanopowder. RF Patent 2681962 C1. 2019. Bulletin № 8.

11. Ivanov L.A., Demenev A.V., Muminova S.R. The inventions in nanotechnologies as practical solutions. Part II. Nanotechnologies in Construction. 2019, Vol. 11, no. 2, pp. 175-185. DOI: 10.15828/2075-8545-2019-11-2-175-185.

12. Shubov L.Ya., Borisova O.N. Disposal of valuable components of municipal solid waste. Housing and public utilities. 2013. No. 8. P. 59-64. 
13. Malkin P. Wastewater treatment from heavy metal ions using nanoactivated complexes of natural zeolite and diatomite. Nanotehnologii v stroitel'stve $=$ Nanotechnologies in Construction. 2018, Vol. 10, no. 2, pp. 21-41. DOI: 10.15828/2075-85452018-10-2-21-41.

14. Koshcheev A.P., Perov A.A., Hatipov S.A. Detonation nanodiamond surface functionalization method. RF Patent 2676975 C2. 2019. Bulletin № 2.

15. Ivanov L.A., Muminova S.R. Nanotechnologies and nanomaterials: review of inventions. Part 1. Nanotehnologii v stroitel'stve $=$ Nanotechnologies in Construction. 2017, Vol. 9, no. 1, pp. 88-106. DOI: 10.15828/2075-8545-2017-9-1-88-106.

16. Slavov I.A., Shvarzman D.I. A method of introduction of single-shell and/or double-shell and/or multi-shell carbon nanotubes in adhesive additive composition for asphalt coating and application of single-shell and/or double-shell and/or multi-shell carbon nanotubes as a part of adhesive additive composition. RF Patent 2675515 C1. 2018. Bulletin № 35.

17. Ivanov L.A. Izobretenija uchenyh i inzhenerov, napravlennye na reshenie prakticheskih zadach [Scientific and engineering inventions designed to solve practical problems]. Innovacii i investicii [Innovations and investments]. 2017. № 5. pp. 164-167. (In Russian).

18. Ivanov L.A., Muminova S.R. New technical solutions in nanotechnology. Part 5. Nanotehnologii v stroitel'stve $=$ Nanotechnologies in Construction. 2016, Vol. 8, no. 6, pp. 65-82. DOI: 10.15828/2075-8545-2016-8-6-65-82.

19. Ivanov LA., Borisova O.N., Muminova S.R. The inventions in nanotechnologies as practical solutions. Part I. Nanotehnologii v stroitel'stve $=$ Nanotechnologies in Construction. 2019, Vol. 11, no. 1, pp. 91-101. DOI: 10.15828/2075-8545-2019-11-1-91-101.

20. Schetinin E.Yu., Prokopiev P.S. Issledovanie jenergosberegajushhih tehnologij v jelektrosnabzhenii umnyh zdanij s ispol'zovaniem iskusstvennogo intellekta [Assessment of energy-saving technologies in the power supply of smart buildings with artificial intelligence]. Finansovaja jekonomika [Financial Economy]. 2019. № 2. pp. 666-668. (In Russian).

21. Levin Yu.A., Pavlov A.O., Prokopiev P.S. Novaja model' razvitija Dal'nego Vostoka: izmenenie finansovoj arhitektury regiona [A new model for the development of the Far East: a change in the financial architecture of the region]. Innovacii i investicii [Innovations and Investments]. 2018. № 12. pp. 260-264. (In Russian).

22. Nikitin A.A., Dinets D.A., Prokopyev P.S. Finansovo-jekonomicheskie i geopoliticheskie perspektivy formirovanija obshhih rynkov jenergii EAJeS [Financial and economic and geopolitical prospects for the formation of common energy markets of the EAEU]. Innovacii i investicii [Innovations and investments]. 2019. № 3. pp. 71-75. (In Russian).

\section{СПИСОК ЛИТЕРАТУРЫ}

1. Пономарев А.Н., Середохо В.А., Софронов А.Ю. Строительный конструкционный элемент // Патент 2683836 РФ МПК С1. 2019. Бюл. № 10.

2. Беккер А.Т., Уманский А.М. Арматура композитная // Патент 2683836 РФ МПК С1. 2019. Бюл. № 10.

3. Жанг Д., Лиу Ю., Ли Г., Су Й., Лианг К., Ву Ю., Ву Ю. Способ изготовления композитного порошкового материала из алюмооксидных углеродных нанотрубок // Патент 2683323 РФ МПК С1. 2019. Бюл. № 10.

4. Губертов А.М., Полянский М.Н., Савушкина С.В., Чванов В.К., Левочкин П.С., Стернин Л.Е. Способ плазменного нанесения наноструктурированного теплозащитного покрытия // Патент 2683177 РФ МПК С1. 2019. Бюл. № 9.

5. Герман С. В., Горин Д.А., Сухоруков Г.Б., Козлова А.А., Северюхина А.Н. Способ формирования многослойного покрытия на частицах и устройство для его реализации // Патент 2683115 РФ МПК С1. 2019. Бюл. № 9.

6. Коцарь Т.В., Данилович Д.П., Зайцев Г.П., Орданьян С.С. Способ получения смесей высокодисперсных гетерофазных порошков на основе карбида бора // Патент 2683107 РФ МПК С1. 2019. Бюл. № 9.

7. Захарова Г.С., Джу Ц. Способ получения композита ортованадат лития/углерод // Патент 2683094 РФ МПК С1. 2019. Бюл. № 9.

8. Колыбельский Д.С., Порфирьев Я.В., Шувалов С.А., Попов П.С., Зайченко В.А. и др. Низкотемпературная пластичная смазка // Патент 2682881 РФ МПК С1. 2019.

9. Махмудиан С., Селлнер И.Н., Стоббе С., Лодал П. Эффективное спин-фотонное взаимодействие при использовании симметричного в плоскости скольжения волновода // Патент 2683836 РФ МПК С2. 2019. Бюл. № 8.

10. Мостовщиков А.В., Ильин А.П., Чумерин П.Ю., Игумнов В.С. Способ дегазации нанопорошка вольфрама // Патент 2681962 РФ МПК С1. 2019. Бюл. № 8.

11. Иванов Л.А., Деменев А.В., Муминова С.Р. Изобретения в области нанотехнологий, направленные на решение практических задач. Часть II // Нанотехнологии в строительстве. - 2019. - Том 11, № 2. - C. 175-185. - DOI: 10.15828/2075-8545-2019-11-2-175-185.

12. Шубов Л.Я., Борисова О.Н. Утилизация ценных компонентов твердых бытовых отходов // ЖКХ. - 2013. - № 8. C. 59-64.

13. Малкин П. Очистка сточных вод от ионов тяжелых металлов с помощью наноактивированных комплексов природного цеолита и диатомита // Нанотехнологии в строительстве. - 2018. - Том 10, № 2. - С. 21-41. - DOI: 10.15828/20758545-2018-10-2-21-41.

14. Кощеев А.П., Перов А.А., Хатипов С.А. Способ функционализации поверхности детонационных наноалмазов // Патент 2676975 РФ МПК С2. 2019. Бюл. № 2.

15. Иванов Л.А., Муминова С.Р. Нанотехнологии и наноматериалы: обзор новых изобретений. Часть $1 / /$ Нанотехнологии в строительстве. - 2017. - Том 9, № 1. - С. 88-106. - DOI: 10.15828/2075-8545-2017-9-1-88-106. 
REVIEW OF NANOTECHNOLOGICAL INVENTIONS • ОБЗОР ИЗОБРЕTЕНИЙ В ОБЛАСТИ НАНОТЕХНОЛОГИЙ

16. Славов И.А., Шварцман Д.И. Способ введения одностенных и/или двустенных и/или многостенных углеродных нанотрубок в состав адгезионных добавок для асфальтового покрытия и применение одностенных и/или двустенных и/или многостенных углеродных нанотрубок в составе адгезионных добавок // Патент 2675515 РФ МПК С1. 2018. Бюл. № 35.

17. Иванов Л.А. Изобретения ученых и инженеров, направленные на решение практических задач // Инновации и инвестиции. Научно-аналитический журнал. - 2017. - № 5. - С. 164-167.

18. Иванов Л.А., Муминова С.Р. Новые технические решения в области нанотехнологий. Часть 5 // Нанотехнологии в строительстве. - 2016. - Том 8, № 6. - C. 65-82. - DOI: 10.15828/2075-8545-2016-8-6-65-82.

19. Иванов Л.А., Борисова О.Н., Муминова С.Р. Изобретения в области нанотехнологий, направленные на решение практических задач. Часть I // Нанотехнологии в строительстве. - 2019. - Том 11, № 1. - С. 91-101. - DOI: 10.15828/20758545-2019-11-1-91-101.

20. Щетинин Е.Ю., Прокопьев П.С. Исследование энергосберегающих технологий в электроснабжении умных зданий с использованием искусственного интеллекта // Финансовая экономика. - 2019. - № 2. - С. 666-668.

21. Левин Ю.А., Павлов А.О., Прокопьев П.С. Новая модель развития Дальнего Востока: изменение финансовой архитектуры региона // Инновации и инвестиции. - 2018. - № 12. - С. 260-264.

22. Никитин А.А., Динец Д.А., Прокопьев П.С. Финансово-экономические и геополитические перспективы формирования общих рынков энергии ЕАЭС // Инновации и инвестиции. - 2019. - №3. - С. 71-75.

\section{INFORMATION ABOUT THE AUTHORS}

Leonid A. Ivanov, Ph.D. in Engineering, Vice President of the International Academy of Engineering, Member of the International Journalist Federation; Gazetny per., block 9, bld. 4, Moscow, Russian Federation, 125009, L.a.ivanov@mail.ru

Petr S. Prokopiev, Student, Financial University Under the Government of the Russian Federation, International Economic Relations Faculty, e-mail: prokopiev2012@gmail.com

\section{ИНФОРМАЦИЯ ОБ АВТОРАХ}

Иванов Леонид Алексеевич, канд. техн. наук, вице-президент Международной инженерной академии, член Международной федерации журналистов; Газетный пер., д. 9, стр. 4, г. Москва, Россия, 125009, L.a.ivanov@mail.ru

Прокопьев Пётр Сергеевич, студент факультета международных экономических отношений Финансового университета при Правительстве Российской Федерации, e-mail: prokopiev2012@gmail.com 